\title{
Movimento Editorial do S.D. do D.A.S.P.
}

$\mathrm{S}$

OMAM algumas centenas as publicações lançadas pelo Serviço de Documentação. Sem recursos técnicos à altura de sua missão, as edições que vem, no entanto, realizando, apresentam um bom indice de qualidade tanto no trabalho de composição gráfica como no de acabamento artistico.

Em conteúdo, refletem com absoluta fidelidade tôda a experiência brasileira em matéria de administração pública. Doutrina e prática administrativas são, com efeito, a permanente preocupa ção dos que têm assinado os mais importantes textos publicados pelo $S$. D. A êsses juntam-se, agora, outros cinco livros que estarão, em breve, em circulação.

Temas de Politica e de Filosofia do Prof. DJacir Menezes, Manual de Serviço dos Processos das Pensões Militares organizado por uma equipe de técnicos do D.A.S.P., Português e Redação Oficial do Prof. VitTorio BERGo, o quarto volume da História Administrativa do Brasil dirigida pelo Prof. LiBÂnIo Guedes e Prontuário de Redação Oficial do Prof. JoÃo Luiz NEY, focalizam sob ângulos diferentes assuntos que, direta ou indiretamente, convergem para a área da ciência da administração. Seus autores são conhecidas autoridades que emprestam às edições do D.A.S.P. o prestígio do renome profissional em cada uma de suas especialidades.

Com um programa elaborado em têrmos objetivos, o Serviço de Documentação espera, nestes próximos meses, ampliar o mo vimento editorial, de modo que, para um público cada dia mais numeroso, se faça cada vez mais presente a divulgação dos estudos, práticas e planos que resultam da atividade administrativa. 